University of Warwick institutional repository

This paper is made available online in accordance with

publisher policies. Please scroll down to view the document

itself. Please refer to the repository record for this item and our

policy information available from the repository home page for further information.

To see the final version of this paper please visit the publisher's website. Access to the published version may require a subscription.

Authors: Mick Carpenter

Title: $\quad$ The capabilities approach and critical social policy: Lessons from the majority world?

Year of 2009

publication:

Link to

http://dx.doi.org/10.1177/0261018309105175

published

version:

Publisher None

statement: 


\title{
The Capabilities Approach and Critical Social Policy: Lessons from the Majority World?
}

\author{
Mick Carpenter \\ Professor of Social Policy \\ Department of Sociology \\ University of Warwick \\ Coventry CV4 7AL \\ m.j.carpenter@warwick.ac.uk
}

\begin{abstract}
The capabilities approach (CA) most closely associated with the thinner and thicker versions of Sen and Nussbaum has the potential to provide a paradigm shift for critical social policy, encompassing but also transcending some of the limitations associated with the Marshallian social citizenship approach. The article argues however that it cannot simply be imported from the majority world, rather there is a need to bear in mind in the critical literature that developed around it. This is generally discussed and then critically applied to case studies of applications of CA in the developed capitalist world, particularly The Equalities Review conducted for the Equality and Human Rights Commission (EHRC).
\end{abstract}

\section{Keywords}

Discrimination, equality, evaluation, human rights

\section{Introduction: A new, improved paradigm for critical social policy?}

Until recently human rights have not been treated as a major issue for mainstream social policy in the minority developed world. On the whole 'core' human rights are seen primarily identified with civil and political (CP) rights and liberties such as freedom of expression and assembly, and voting rights, rather than extensive economic and social (ESC) rights to full employment, social security and social provision. While T H Marshall (1948) did formulate a theory of the relation between them, this holistic focus has been largely lost. Since then social policy has largely confined itself to the analysis of social citizenship rights. In this article I argue that the capabilities approach (CA) potentially provides a robust and politically progressive means of re-connecting these issues within a broad human rights discourse. At the same time it can also enable us to address many of the problems identified with Marshallian social policy, such as its exclusive focus upon (and defence of) class inequality, its silence on issues of 'race', age, gender, sexuality and disability, and its nation-bound Anglocentric focus (e.g. Williams, 1989). 
Rather than seeking to bend the citizenship paradigm in increasingly contorted directions, there is arguably a need for a paradigm shift in critical social policy. This should arguably involve a broad and inclusive focus on human rights bringing both CP and ESC rights into a single frame of holistic analysis focused on people's needs and entitlements. This would raise questions about how to frame rights of people within a particular society such as the contemporary UK, regardless of their political status as 'citizens', and also compel us to be concerned about the needs and rights of people everywhere. In Britain the need for such a shift in critical social policy has been pressing since the 1998 Human Rights Act (HRA) incorporated the 1950 European Convention on Human Rights (ECHR) into British law.

Subsequently the Equality Act 2006 established a Commission on Equality and Human Rights (CEHR) for Great Britain mirroring one established for Northern Ireland in 1999. This drew together human rights and a raft of new or revised anti-discrimination legislation in 'race', gender, disability, gender, religion and belief, age and sexual orientation into a single system of governance.

According to McLaughlin (2007: 111) this system creates a 'new equality architecture' which puts 'the UK at the forefront of international developments in equality law'. However the ECHR is nearly 60 years old and currently mainly restricted to basic CP rights. A campaign has thus ensued since 1998 to include ESC rights in a broader UK Bill of Rights, in line with the UK's treaty obligation since 1976 under the United Nations International Covenant. The Parliamentary Joint Committee on Human Rights (2008) has endorsed calls for a UK Bill of Rights and Freedoms. Superficially there is a cross party consensus on the need for new legislation, but this masks different agendas. Politicians of both major parties were initially queuing up to respond to right wing tabloid accusations that the HRA was a 'charter' for criminals and terrorists. Subsequently in 2007 Gordon Blair published a Green Paper on constitutional reform early in his premiership. A key feature was a proposed 'British Bill of Rights and Duties' with the aim of codifying British citizenship to cement national identity as a unifying principle in a society increasingly splintered by class, ethnicity, race, gender, disability, sexuality, age and faith (Secretary of State for Justice and Lord Chancellor, 2007). Chapter 3 of the Joint Committee Report addresses nationality issues in ways that differentiates its approach to the Green Paper first by calling for a 'Bill of Rights and Freedoms' (emphasis added). Rather than reigning in CP rights it calls for a 'HRA plus' which extends these beyond the 'floor' of the ECHR and also adds ESC rights. It called for the government to 'decouple' questions of Bill of Rights from 'the rights and duties of the citizen' and make a clear commitment to their universal application to residents of Britain, along with an outward rather than inward looking approach to 'British values'. It goes on to argue that as well as non-citizens such rights should be extended to cover 'vulnerable' groups such as children, disabled people, workers including migrants, victims of crime, and members of religious, linguistic and ethnic minorities (op. cit: 41-2). The Report particularly identifies asylum seekers as a group denied human rights (op. cit.: 56 ). It also endorses the inclusion of socalled 'third generation' rights, i.e. those beyond traditional CP and ESC 
rights, particularly the right to a healthy and sustainable environment (op. cit:: 59).

An extended analysis of the politics of a Bill of Rights is beyond the scope of the current article, including the question of whether constitutional entrenchment and judicial oversight is the best road to realising rights. There are dangers involved in that a future Cameron Conservative government might try to enact a limited basket of rights entrenched through a German style Basic Law, preventing Parliament in future from extending civil or social rights (Charter, 2006). All the more important then that the Joint Committee has set a progressive benchmark for the future, one that shows the complex interconnections and dissonances between human rights and citizenship rights discourses, and indicates ways that a renewed commitment of principles of universalism and diversity can be realised.

It is true that human rights have been receiving more attention in social policy but usually this has involved either focusing on international issues or the most marginalised groups in the UK, rather than seeing it as a mainstream issue linking the two. It is starting to happen with Dean (2007) arguing that human rights are often restricted to a CP discourse and social policy can ensure a stronger emphasis on 'welfare' or ESC rights. Equally however social policy could be castigated for ignoring CP rights. The division between the two was the product of a world polarised by the Cold War and with the demise of state communism and triumph of global neoliberalism, narrow views of human rights predominated excluding ESC rights defining freedom 'negatively' in terms of liberal democracy and free markets. However this has also been strongly contested by social movements and activists and following the World Conference on Human Rights, the 1993 Vienna Declaration and Programme of Action emphasized the indivisibility of CP and ESC rights.

Against this background, this article therefore examines the potential of the capabilities approach (CA) to provide a holistic framework for integrating critical social policy and broad human rights concerns consistent with the approach taken by the Joint Committee. A characteristic feature of CA, as we shall see, is an insistence that civil freedoms, democracy, social opportunities and equalities are interdependent. The basis for such an integration has already been laid as CA, developed originally by Sen (1999) and extended by Nussbaum (2000) to inform development policy in the majority world, will provide 'equality benchmarks' by which the EHRC will judge progress up to 2010 and beyond, following the work undertaken by The Equalities Review (2007). CA is a human rights informed theory and set of methodologies which arose to challenge orthodox neoclassical economics and neoliberal ideologies of progress human focused solely on economic growth and per capita income, and was a key influence in the development of the United Nations (UN) Human Development Index (HDI) in 1990. Yet though it has considerable potential to facilitate a paradigm shift for critical social policy, if its progressive potential is to be realised it must be embedded in an internationalist human rights approach. This must also take due account of the critical debates that have surfaced around CA's approach to development in the majority world that make it at best a partial challenge to global capitalist agendas. 
As Freeman (2002: 6) argues human rights are not 'things' which either do or do not exist, rather they are contested 'just claims or entitlements that derive from moral and/or legal rules' (original emphasis). He also argues that determining what these might be requires a 'theory of human rights' to show how these might be 'validated'. Liberal 'negative' conceptions of CP rights were often premised following Locke on a pre-social 'natural rights' of the individual. In reaction to this following Bentham 'legal positivist' conceptions denied such foundational connections and sought also to separate questions of law from ethical considerations. CA, as well as integrating CP and ESC rights, also potentially transcends this epistemological polarisation. While moral and ethical in orientation, it can be ontologically grounded in social scientific knowledge about 'what it is to be human', connecting this to a realist theory of 'need' such as that developed by Doyal and Gough (1991).

\section{The Capabilities Approach through Thick and Thin}

While there is a vast literature ${ }^{1}$ capabilities research has generated two main paradigms, the 'thinner' version of Sen (1999) in Development as Freedom (hereafter DF) and the 'thicker' version of Nussbaum $(2000,2001)$. The basic tenets of CA are simple though they open up issues of considerable philosophical, political and sociological complexity. Essentially they address central enlightenment themes about how to judge human progress, how to reconcile liberty and justice, and how to take account of both procedural and substantive requirements for ensuring social justice. CA does not imply these are easy issues to reconcile, but there is an in-built optimism about the possibilities for rational action and achieving fair results. As a result CA tends to be prescriptive and evaluative, rather than explanatory, which gives rise to some significant problems. There are also substantial questions about operationalizing $\mathrm{CA}$, and the role of government and civil society in implementing it.

CA asserts the essential similarity of our human needs and potentialities. It is a holistic and humanistic approach that places the whole person - what we are able to do or be - at the centre of social analysis and public action. In Sen's thinner and classic formulation capabilities are the abilities and possibilities that we acquire in order to exercise 'valuable functionings' or 'beings and doings'. These are the outcomes we individually or as a result of our cultural values believe would constitute 'the good life', to enable us to 'flourish' as human beings and achieve 'personhood'. The expansion in available commodities made possible by the global market in his view facilitates this, but it is not an end in itself. Thus Sen disputes that economic growth or consumption of goods are in themselves markers of progress, as they may or may not expand capabilities and functionings. Valuable functionings also include non-market activities such as religious practices, social activities and caring work. Notions of progress or 'human development' therefore must embrace a wider inventory. Sen's emphasis on 'freedom', not just 'choice', is central. While he strongly defends liberal democracy against communism, colonialism and other forms of authoritarian rule, he goes further by embracing the idea of 'substantive freedoms'. This goes beyond the 
'negative' concept of liberty from the state championed historically by the rising middle class. It fleshes out what is meant by a 'positive' concept of liberty (Berlin, 1969) as public action to make freedoms available to those who would otherwise be denied them, as advanced by labour and socialist movements.

Sen's emphasis on substantive freedoms critiques of the limitations of free markets, and makes a strong argument in favour of public goods. The way that he develops this, however, generates tensions between individual and collective capabilities, which has been much debated. On the one hand Sen argues for the 'freedoms of individuals as basic building blocks' (DF: 18). On the other, he argues for public goods that cannot be delivered by individuals pursuing their rational self-interest. Thus, it is not possible to buy a malaria free environment. He defends social provisioning in basic education can also be cheaper and more effective than private provision (DF: 128-9). Although Sen's work grew out of the 'basic needs' development approach from the 1970 s, with an emphasis on nutrition, primary health care and education, it also encompasses complex functionings such as artistic or sporting accomplishments. CA recognises that people are not equally placed to realise their human capabilities, due to barriers arising from structural inequalities of class, 'race', disability gender and sexual oppression. Tackling these is central to CA's theory of social justice, distinguishing it from the Rawlsian approach which has influenced New Labour (e.g. through the work of the Commission on Social Justice (1994). Rather than redistributing a minimum of necessary goods solely through a basic income (Rawls, 1999), CA is outcome rather than input focused and insists that some people may require additional resources to develop capabilities and transform them into functionings ('conversion factors'). A wheelchair user may not for example be able to buy access to the public sphere if there are steps barring their access to a public library or if discriminatory processes restrict their employment opportunities (DF: 73). Thus CA takes account of the fact that playing field is bumpier for some groups than others, and offers ways of reconciling principles of equality and diversity in social justice.

In contrast to the dominant utilitarian approach associated with neoclassical economics and neoliberal ideology, which values subjective outcomes such as wants, desires, and 'the pursuit of happiness', CA is more grounded in what people are and do, their 'valuable beings and doings' (DF: 75). The notion of 'valuable' implies ethical and political judgements, in other words discrimination between functionings some of which might be regarded as reprehensible (Alkire, 2005: 121). Some needs might be considered more important than others, consistent from the priority given to 'basic needs'. Philosophically CA draws selectively on Marx's conception of 'alienation' and vision of reforming society to bring it in line with our creative and associative natures, and more extensively on Aristotle's ethics on the purpose of humanity being to realise the 'good life' (. The goal of economic and public policy is thus defined as 'a process of expanding the substantive freedoms that people have' (DF: 297). Thus Sen cuts through the reductionism of orthodox economics to place human beings at the centre. However his position remains ambiguous, involving bedrock though conditional support for 
the market and economic growth, technical growth and modernisation, if they enhance substantive freedoms.

There is considerable overlap between Sen and Nussbaum, though the latter focuses less on welfare economics than philosophical debates about social justice, strongly animated by liberal-humanist feminist principles. While Sen's is a general model of capabilities, Nussbaum (2000) specifically seeks to put claims on government. While Sen permits the democratic process to arrive at capabilities for a culture, Nussbaum sees personhood as giving rise to certain universal preconditions for the exercise of capabilities which governments should aim to guarantee. Robeyns (2005: 104) argues that as a result Sen's approach is more formally objectivist and concerned with questions of measurement, while Nussbaum's is experientially concerned with personal 'narrative', in order 'to better understand people's hopes, desires, aspirations, motivations and decisions'. It is thus more open to qualititative research and participative approaches to evaluation.

Nussbaum (2000, 2001), places more emphasis than Sen on 'adaptive preferences'. Nussbaum critiques the 'subjective welfarism' inhibiting orthodox economics from making judgements about 'tastes' and 'preferences' expressed through market choices. She argues that for oppressed and poor people 'habit, fear, low expectations, and unjust background conditions deform people's choices and even their wishes for the own lives' (Nussbaum, 2000: 114). She cites examples of Indian women whom she worked with tolerating domestic violence and discriminatory wage systems rather than seeing them as a violation of their rights, as 'this was how things were and would be' (Nussbaum, 2001: 68). People's existing preferences and judgements of needs are thus not necessarily a reliable basis for policy, because of the problem of 'preference deformation'. Nussbaum is aware that there are parallels with Marx's much criticised concept of 'false consciousness'. This is one reason why she departs from Sen in arguing for a list of 'central human capabilities' open to public scrutiny, discussion and amendment over time, to be incorporated in all constitutions. These are specified as a list of 10 capabilities in Figure 1. It is important to realise that neither Sen nor Nussbaum propose extensive equality, rather minimum thresholds to enable all humans to flourish.

[ Figure 1 near here]

\section{Sen and Nussbaum: Critics or Critical Friends of Market Neoliberalism?}

In appearing to offer a happy medium between liberal and socialist principles, reconciling universalism and diversity, is CA a hopelessly contradictory exercise? I do not think so, but while CA is a promising paradigm for a realisable project, the dominant versions fail to sufficiently critique liberal individualism, have an inadequate theory of the state within global capitalism, and a naïve essentialist view of the market. As a consequence mainstream 
$\mathrm{CA}$ is not as interventionist and egalitarian as at first sight appears, and as a fuller practical realisation of CA principles might require. However while Sen and Nussbaum cannot be portrayed quite as saintly anti-market scourges of neoliberalism, I do not think they can be simply dismissed as individualist market wolves in capabilities clothing. There is rather a mismatch between the laudable and ambitious aims of CA and the more limited means proposed for realising them.

Considerable criticism of mainstream CA has centred on its liberal individualist framework and the failure to sufficiently acknowledge the extent of group capabilities (e.g. Robeyns, 2005). While CA acknowledges group influences on individual capabilities, it does not explicitly sanction them at the collective level, e.g. the efforts of labour and other social movements, for example ethnic minorities, disabled people, or Lesbian, Gay, Bisexual and Transgender (LGBT) to sustain a collective cultural integrity and resources in the face of a hostile society. Thus Evans (2002: 56) argues that Sen is a 'good Manchester liberal' who 'focuses on individuals and their relation to an overall social context, not on collectivities as the necessary link between the two'. Other suggest that Sen's theory is a modified form of neoliberalism, consistent with the 'post-Washington consensus' that emerged out of the critique of the unbridled market in the 1980s and failure of structural adjustment policies (SAPs). It highlights the need to bring the state back in to correct some of the worst effects of the market, without fundamentally restricting its influence, consistent with Third Way discourses. Sandbrook (1999: 1071) depicts Sen as an eloquent defender of the free market system 'far removed from the crude reductionism of orthodox neoclassical analysis'. A close reading of Development as Freedom readily provides examples of how a radical CA rhetoric is combined with a quite conservative economic policy supportive of monetarist restrictions on public spending, what he calls 'fiscal prudence' (DF:130). Sen also expresses concerns that unemployment insurance may be problematic in reducing incentives to market labour, and acknowledges that questions may be raised concerning the availability for free health care and education on grounds of need and ability to pay (DF: 130). He accepts in principle that there may be a case for means-testing though its implementation may cause problems (DF: 134-7).

Sandbrook argues that all this is consistent with the shift to the Comprehensive Development Framework (CDF) introduced by the World Bank President, James Wolfensohn in 1999. This aims to improving the effectiveness of development assistance in reducing poverty through a longterm, 'results' or needs-based outcome focus. It claims to be democratic rather than top down, by fostering country-led partnerships with the private and voluntary sector, linked to the UN's Millennium Development Goals (MDGs). Klees (2002) has argued that the shift from 'pure' neoliberal SAPs enforced by the International Monetary Fund (IMF) and the Bank to a less apparently dictatorial partnership approach with countries through the sector wide approaches (SWAPs) associated with the CDF, was an attempt to give some ground to incorporate critical NGOs (Klees 2002: 111). Sandbrook argues that Sen reifies the market as natural and 'essentialist', and largely celebrates the efficiencies and expansion of goods that it entails, with strong 
echoes of Hayek and Adam Smith. The pages of Development as Freedom have few references to multinational corporations, or the role of international institutions like the IMF or World Bank, let alone the effects of the US as a dominant world power in a post-communist world.

$\mathrm{He}$ and Nussbaum tend to presume the existence of a world in which the state basically has sovereignty over its affairs and there are few external constraints upon it. Modernity or adherence to a tradition is sometimes seen by Sen as a political choice that states and societies can exercise, if at cost to efficiency. However in the next breath he portrays globalization as both an autonomous and unstoppable force, and the best that can be done is to slow it down, and offer people transitional support, echoing Third Way approaches (DF: 241).

Robeyns (2005) does acknowledge that CA needs to be supplemented by a theory of causes, rather than simply being normative and pragmatic. However there is a danger that this will only be developed superficially, rather than identifying and targeting deeper drivers, or what critical realist analysis calls deeper 'generative mechanisms' (Bhaskar, 1975). As a result CA tends to seek to empower people in ways that involve modified reproduction of market and other social relations, not acknowledging that emancipation might require their collective transformation (see Joseph, 1998). Thus Navarro (2000) argues that power relations and inequality are under-theorized by Sen. Bagchi (2000: 4412) complains that Sen underplays the ways that market expansion perpetuates unfree forms of labour, and his celebration of liberal democracy is not a realistic portrayal 'of how actually existing democracy operates under the capitalist order'. Both Zimmerman (2006) and Jackson (2005) have focused centrally on the individualist limitations of Sen's theory, and the ways in which social structures, power and culture are only partially acknowledged. Zimmerman argues that Sen largely sees the wider environment as a context shaping individual agency, rather than developing a more sociologically grounded interactive or relational model. Jackson traces this to an incomplete critique of neoclassical economics, and an excessive faith in liberal political theory. He advocates linking CA to critical sociology, something which is in its early days. Sayer (2005) for example has begun to sketch out linkages between a realist approach to class based on Bourdieu's conception of the 'habitus', and Nussbaum's thicker approach to CA. Thus while much of the critical discussion has centred on Sen, latterly Nussbaum has deservedly been receiving more attention. For example, Menon (2002), though sympathetic to her intentions argues that she does not give sufficient support to mass movements from below of workers and citizens, but encourages reliance on a paternalistic state. She particularly criticises the failure to consider the impact and implications of US world dominance.

Though there is plenty of scope for engagement between social policy and $\mathrm{CA}$, in the past this has not been cordial, as the famous debate about poverty analysis between Sen (1985) and Townsend (1985) in the 1980s indicates. It arose because CA disputed the validity of a poverty line, based on incomebased measures of poverty as limited, because of its concern with capability outcomes and variable conversion factors. However, despite caustic 
exchanges, there was potential common ground between them. Both had faith in 'objective' positivist measurement, and Townsend's relative definition of poverty as resources necessary for participation in a culturally prescribed way of life, involved a shift to a multidimensional concept of 'deprivation', not that removed from Sen's concept of 'flourishing'. Both also failed to analyse the wider culture sufficiently, and the relational linkages of poverty to wider drivers of class inequality (Novak, 1996). However, as we have seen, Townsend was not alone in criticising a tendency he saw in Sen to residualism and limited state intervention. The dominant approaches to CA are clearly concerned with setting 'minimum thresholds' than pursuing extensive equality of outcomes.

\section{Applying CA to the Majority World: Selected Critical Case Studies}

The above discussion indicates that CA should be a starting rather than finishing point. Operationalizing it as an evaluative strategy raises political and not simply technical issues. There is a need to foreground wider structures of power and inequality, and the extent to which more extensive change may be required to significantly improve human flourishing, with groups not just individuals being the basis for transformative social action.

Undoubtedly CA provides support for a broad social policy agenda, in contrast to the limited neoliberal project of the market plus liberal democracy and consumerism. It acknowledges that there is 'such a thing' as society, with equality and social justice requiring social and political intervention. It chimes with a growing awareness that economic growth and wealth expansion does not guarantee happiness or an improved quality of life (QoL) such as argued by. Layard (2005). However, as Rustin (2007) argues CA can provide a powerful critique of the utilitarian subjectivism that typically inform this new 'science', providing the basis for a fuller and more dynamic view of quality of life (QoL) focuses more on 'fulfilment' than simply gratification.

Thus though CA in some ways chimes with Third Way social policy and advocacy of an 'enabling state', its broad vision goes beyond the utilitarian calculus and Rawlsian basic income approach that has strongly influenced New Labour project. However the wider emphasis on combating social exclusion and multidimensional poverty, and tackling discriminatory barriers, opens up a wider agenda consistent with CA. Yet while there is rhetoric towards enablement and empowerment, there is a strong illiberal emphasis on compulsory integration, especially enforced participation in low paid work. Simply making people a bit better off by 'making work pay' does not necessarily enhance capabilities once people are in work (Carpenter and Speeden, 2007). CA foregrounds these issues, favours local agency through decentralisation against top-down targeting, and acknowledges that people may legitimately value caring or community over market work (Dean et al, 2005). It is however less useful in helping to foreground macroeconomic and social policies that address structural disadvantage and demand side causes of unemployment and low pay. It is true that New Labour's 'social investment 
state' (Giddens,1998) does challenge pure neoliberalism by pointing to the potentially productive effects of public expenditure. However humanistic concern are sidelined by the priority given to the return to capital through employability, skills enhancement and responsibilising of individuals (Clarke, 2005). By contrast a 'capability state' would primarily defend entitlements on the grounds of social justice and people's wellbeing, with the onus being to showing how capitalist economic growth might contribute to or conflict with this goal.

$\mathrm{CA}$ is gaining ground as a way of informing progressive social policy in developed capitalist societies. For example, the European Union's conceptual shift from a narrow income poverty perspective to a multidimensional 'poverty and social inclusion' has been strongly influenced by Sen via the work $u$ by Atkinson (2002) for the European Commission, covering financial poverty defined in terms of $60 \%$ of the national median, income inequality, employment, health and education. Eighteen Level 1 and 2 'at risk of poverty' outcome indicators have been developed under these headings harmonised across the EU. Under the Open Method of Coordination (OMC) EU governments are 'invited' to set targets through National Action Plans (NAPs) and assess their progress against them, adding Level 3 indicators of their choosing. This corresponds to a stronger EU intervention on social policy alongside the market liberalisation strategy, a broadening of its traditional focus on employment policy, and a growing integration of economic and social policy as part of the Lisbon Strategy. Two points can be made here as part of a provisional assessment. First, Nolan (2003) argues that there is a need to develop the indicators further to include housing and homelessness, social participation and access to services, and to strengthen gender dimensions, and deepen health to include health inequalities. In other words, the current Social Indicators only implement CA to a limited extent. Second, the 'soft law' associated with the OMC contrasts with the firm law to implement the market, and hence currently subordinates social to economic considerations (O'Connor, 2005). Salais and Villneuve (2005) have argued that CA offers the prospect of a more genuinely 'social' Europe at odds with the Lisbon Strategy. At the national level, in 2005 Germany's National Action Plan for Social Inclusion drew explicitly on Sen for its national poverty and wealth reports (Arndt and Volkert, 2007: 22). However this has not been without controversy, as there have been accusations that the methodology significantly underestimated the rapid growth in material poverty between 1999 and 2005 (Craigslist Heidelberg, 2008).

There are a growing number of examples of efforts to apply CA to contemporary health and social policy, and in the process its overlap with over progressive frameworks becomes visible. Thus Burchadt (2004) argues that the social model's distinction between impairment and disability as a socially constructed discriminatory process, developed by the disabled people's movement, has direct parallels with CA. Hopper (2007) argues that CA is consistent with a 'social recovery' model of schizophrenia which acknowledges a significant degree of impairment, but is optimistic than social provision can facilitate empowering participation in society. This needs to go alongside efforts to address wider disabling barriers associated with 
'patienthood' to realise a potential for personhood. Yet by far the most ambitious application of CA in the UK, has been The Equalities Review (2007) Fairness and Freedom (hereafter FR) decision to establish CA as the evaluative framework for the Equality and Human Rights Commission (ECHR) work.

The Equalities Review, chaired by Trevor Phillips as head of the ECHR, audited past UK progress on equalities and established the criteria by which it would be further benchmarked up to 2010 and beyond. The language of the Report is restrained but it makes clear that while 'progress' had been made over the past decade on equality fronts it was so slow that at current rates it will decades before substantial equality for the groups covered by the ECHR will be achieved. In calling for a renewed commitment to achieving equality the report proposes a new definition of an equal society which is virtually a paraphrase of Sen:

An equal society protects and promotes equal, real freedom and substantive opportunity to live in the ways people value and would choose, so that everyone can flourish. An equal society recognises people's different needs, situations and goals and removes the barriers that limit what people can do and can be (FR: 6).

The Report gives due recognition, up to a point, to economic inequality but sees this primarily as the result of poverty divorced from relations of class inequality. It also audits progress across a range of discriminations addressed by the recent spate of equalities laws. It develops a positive view of equality, clearly implying that human rights needs extending to cover ESC as well as $\mathrm{CP}$ rights, drawing on CA's concept of substantive freedom as

Freedom from poverty, discrimination and disadavantage, but also freedom to be able to achieve the things that, individually, matter most to us. A more equal Britain would be both fairer and freer in the full meaning of these words, and is a goal worthy fighting for (FR: 141).

The Review draws attention to challenges such as globalisation and demographic changes, the combined effects of which are leading to greater ethnic diversity, more older people, and increasing numbers of disabled people. Undoubtedly contemporary inequality is multidimensional, and not all the drivers are political economic in origin. However, they remain significant and class relations have significant impact on other forms of inequality. The Review early on limits the debate about action by claiming that it is self evident that the 'old approach of a top-down state which pulls levers to improve outcomes for particular groups is no longer appropriate or effective' (FR: 7). It thus seeks to align CA with a New Labour supply side approach based on partnership between the state, employers, communities and citizens. Since this has been the model adopted since 1997, this begs the question of how such a system can be expected to lead to speedier advance in the future. The answer does not appear to be a more concerted attack on structural drivers of inequalities. This is reinforced by a view that: 
... greater equality will benefit everyone, and not just those currently disadvantaged....(It) will make our society better off, our economy stronger, our social fabric more cohesive ( $p$ 19).

The Review thus largely rules out the possibility of significant structural intervention detrimental to entrenched interests to shape drivers as equality is in the interest of 'everyone'. What it calls the 'economic', 'social cohesion' and 'moral' cases for equality are all seen to coalesce, and there is a reluctance to envisage that they might at least sometimes conflict e.g. that there might be an economic or social cost worth paying to enhance equalities by favouring some people over others. Instead The Review mostly proposes better governance (what it calls 'tools') is the main way forward. Considerable emphasis is placed on holding politicians, and public and private sector organisations to account against the sophisticated and extensive CA outcome domains, combined with improved targeting policies, and more assertive public procurement policies to help tackle what more equality more rapidly ' it acknowledges are 'persistent inequalities'.

Fairness and Freedom is undoubtedly a sophisticated practical application of CA which, as Burchadt (2008) one of its key architects argues, substantially answers critics' arguments that it cannot be operationalized except in rather crude ways. It hence has implications for similar coordinating equality bodies being set up in other EU countries. She argues that there is a need to show that CA provides a way integrating human rights and equality, with antidiscriminatory action, which since 2006 is the remit of the ECHR, in ways that enhance both. In particular, she argues that it can handle effectively the 'intersectionality' of a range of discriminations, some of which may come into conflict with each other, most notably sexuality and religious belief. Burchadt explains how, rather than starting directly from either Sen or Nussbaum, the research constructed 'core' benchmarks from the International Covenants on CP and ESC rights, to which the UK has treaty obligations. This was combined with a more subjectivist approach via a 'deliberative consultation', involving an Ipsos-MORI survey backed up by workshops and individual interviews. The aim was to arrive at a consensus on what constituted the 'good life' needed for people to flourish. Burchadt acknowledges that the research was not as extensive as it might have been. However, she asserts that the results are a sufficiently valid for use by all public bodies not just the EHRC, combining 'statutory' and participative elements, in terms of the 10 equality benchmarks listed in Figure 2 below.

\section{[ Figure 2 near here ]}

Interestingly, some of the items that emerged spontaneously bore comparison to Nussbaum's list including hope, joy and celebration, having goals, and being close to nature (Burchadt, 2008: 214). One of the criticisms that Gough (2002) makes of Nussbaum's model compared to the theory of need developed with Doyal (Doyal and Gough, 1991) is that she is too focused on optional or disputable elements. However they do appear to be high on people's own list of expressed needs. A separate capabilities list will be 
developed for children, but there are no plans to extend this to other groups. This consensual approach highlights a tension in CA in giving recognition to diverse groups, but not always allowing them sufficient scope to define their own needs. Others such as Clark (2006) have therefore pioneered participative approaches. There is a need to be wary how 'adaptive preferences' may sometimes scale down peoples' aspirations, while at others group aspirations may radically challenge mainstream opinion and practice. While Burchadt and the Review suggest that group struggle has led to a 'pragmatic consensus' around recognition that will develop further in future, a conflict perspective might more realistically depict this as a compromise shaped by power realities. However this would of course mean a state body seeing going beyond reconciliation of 'stakeholder' interests to actively side with disadvantaged and oppressed people.

One of the key issues in this regard is the neglect of working class capabilities, which receive only brief mention in The Review. There is of course no anti-discrimination law against class, for good reason because it were to tackle it seriously it would fundamentally interfere with the basic operation of a capitalist society. As Bromley (2000: 51-2) argued, under New Labour, class became 'the ghost in the machine of contemporary British politics, the "great unspoken" which is the source of the fear and anxiety which seems to motivate much current political discourse'. Instead class became fragmented into a range of pathologies such as law and order, welfare mothers, worklessness etc seen as candidates for piecemeal social engineering rather than symptoms of structural malaise. In addition, though The Review is broad, it fails to highlight the discrimination and exclusion experienced by refugees and asylum seekers, and illegal workers, indicating that it was working more within the bounds of an exclusionary citizenship than an inclusive human rights paradigm.

The Review talks of limited progress. While there have undoubtedly been have been equality gains since 1997 there have also been reversals, especially on CP rights. Among other things the right not to detained without trial has been seriously compromised in the name of the 'war against terror', the right to protest significantly compromised by the 2005 Serious Organised Crime and Police Act (SOCRA), extradition to the US since 2003 can now take place without an evidential justification (but not reciprocally), and the government has defended the legitimacy of evidence extracted by torture. In addition the boundaries of criminal behaviour have been significantly extended by the introduction of Anti-Social Behaviour Orders (ASBOs) and 'summary justice' empowering police to impose fixed penalty notices (source for above: Atkins et al, 2007). New Labour has also extended conditionality of benefits and compulsory participation in low paid work (Carpenter and Speeden, 2008) None of these developments receives any mention in The Review, though since CA rightly frames CP as inseparable from ESC rights, it arguably should at least have drawn attention to them and the equality implications.

In the ESC rights spheres of poverty and inequality, things have taken a turn for the worse since the Review was published. Poverty increased in 2006-7 
for the second successive year, particularly affecting children, parents, pensioners and working-age childless adults. Income inequality as measured by the Gini coefficient has risen back to its highest ever level of 2000-01, the highest since comparable records began in 1961 (Brewer at al, 2008). The Review does not mention that New Labour has failed to reduce the inequality gap that widened under the Conservatives from 1979-97. This makes its policy approach appear rather timid and unlikely to deliver more than modest advances, welcome though these would be. The policy recommendations have very little to propose in terms of wider policy measures that could set a framework for greater 'leverage' on inequalities, such as redistributive social policies and extending the positive duties from the public to include the private sectors, as we have seen are not part of the government's 2008 draft Equality Bill. In other words there is a failure to fully address the structural conversion factors that could really make a difference to equality outcomes. Since The Review was published, the end of the economic boom in 2008 and consequent recession is likely to impact most on those who benefited least in the years of plenty, and disrupts assumptions that the economy can simply be left to its own devices to deliver general prosperity.

\section{Conclusion: Towards the Revival of Ethical Social Policy?}

This article has conducted a critical but sympathetic review of CA as a potential paradigm for contemporary social policy in the developed capitalist world, focusing particularly on the work of the 2007 Equalities Review. CA is a conceptually sophisticated and practically realisable framework which appears to provide a means of reconciling a liberal emphasis on freedom with socialist collectivism, and balancing universalism with particularism. The Equalities Review has operationalized it in ways which to some extent, though not sufficiently, fulfils Fraser's (1995) call to combine a politics of 'redistribution' and 'recognition'. CA has helped to rally opposition to neoliberalism at the global level and raised possibilities of pursuing a holistic approach to progress and development centred on the needs and aspirations of people, and lessons from it are now being drawn from the majority to the minority world. However I have sought to show that in doing so, if its full potential is to be realised, there is a need to connect it to a fuller political economic and social analysis that transcends the limited critique of growth oriented global capitalism embedded in mainstream CA approaches, developing a radical capabilities approach that addresses the contradiction between them.

This article was written in the summer of 2008 when the political and economic derailing of the New Labour project had become apparent. Cruddas and Rutherford (2008) argued in The Guardian that part of the problem is that New Labour has been pursuing a 'contractual' politics that eschewed 'fraternal' concerns about 'society, wellbeing and relationships', creating a vacuum the Conservatives are seeking to fill:

The Labour government, (the new Conservatism) argues, has failed because it has abandoned the fraternity of ethical socialism in favour of state management 
CA can help restore normative principles to social policy analysis which have been substantially evacuated since Tawney and Titmuss, at the same time transcending their nationalistic myopia. However, an appeal to reason and normative principles is not sufficient, and political struggle is necessary which Sen and Nussbaum - and the Equalities Review - at least partially acknowledge. CA also potentially offers an alternative to postmodern deconstruction, defining scope for more than critique and negative resistance and critique, but positive alternatives that provides a flexible 'grand narrative' that also connects to other critical discourses, if can become more deeply embedded in critical sociology and political economy, and connect domestic rights fully to wider human rights.

\footnotetext{
Note

${ }^{1}$ A good place to start is the web pages of the Human Development and Capability Association (HDCA) which though partisan, provides access to interesting guides and critical bibliographic sources (www.capabilityapproach.com). The Journal of Human Development also regularly presents papers debating various features of $\mathrm{CA}$.
}

\section{References}

Alkire, S. (2005) 'Why the Capability Approach?' Journal of Human Development, 6(1): 115-33.

Arndt, C. and Volkert, J. (2007) A Capability Approach for Official German Poverty and Wealth Reports: Conceptual Background and First Empirical Results, IAW Discussion Paper 27, Tübingen: Institut fur Angewandte Wirtschaftsforschung, http://www.iaw.edu/RePEc/iaw/pdf/iaw dp 27.pdf

Atkinson, T., Cantillon, B. Marlier, E. and Nolan, B. (2002) Social Indicators: The EU and Social Inclusion, Oxford: Oxford University Press.

Bromley, R. (2000) 'The Theme That Dare Not Speak its Name: Class and Recent British Film', in Munt, S. (ed) Cultural Studies and The Working Class: Subject to Change, London: Cassell, 51-68.

Berlin, I. (1969) Four Essays on Liberty, Oxford: Oxford University Press.

Bhaskar, R. (1975) A Realist Theory of Science, Brighton: Harvester.

Brewer, M., Muriel, A., Phillips, D., and Sibieta, L. (2008) Poverty and Inequality in the UK: 2008, London: Institute of Fiscal Studies, http://www.ifs.org.uk/comms/comm105.pdf.

Burchadt, T. (2004) 'Capabilities and Disability: the Capabilities Framework and the Social Model of Disability', Disability and Society, 19(7): 735-51. 
Burchadt, T. (2008) 'Monitoring Inequality: Putting the Capability Approach to Work', in G. Craig, T. Burchadt and D. Gordon (eds) Social Justice and Public Policy: Seeking Fairness in Diverse Societies, Bristol: Policy Press: 205-29.

Carpenter, M. and Speeden, S. (2007) 'Capabilities, Human Rights and the Challenge to Workfare', in M. Carpenter, S. Speeden and B. Freda (eds) Beyond the Workfare State: Labour Markets, Equalities and Human Rights, Bristol: Policy Press: 159-84.

Charter, D. (2006) 'We Should Have a Bill of Rights to Stop MPs Medding, say Tories', The Times, 26 June.

Clark, D. A. (2005) The Capabilities Approach: Its Development, Critique and Recent Advances, Oxford: Global Poverty Research Group Working Paper 32, http://www.gprg.org/pubs/workingpapers/pdfs/gprg-wps-032.pdf

Commission on Social Justice (1994) Social Justice: Strategies for National Renewal, London: Vintage.

Craigslist Heidelberg (2008) Germany: The growing Gulf between Rich and Poor, 5 May, http://heidelberg.de.craigslist.org/pol/693538681.html.

Crudas, J. and Rutherford, J. (2008) 'Out-thought by the Tories', The Guardian, 10 May.

Dean, H., Bonvin, J.-M., Vielle, P. and Farvarque, N. (2005) 'Developing Capabilities and Rights in Welfare to Work Policies', European Societies, 7(1): 3-26.

Doyal, L. and Gough, I. (1991) A Theory of Human Need, Basingstoke: Macmillan.

Fraser, N. (1995) 'From Redistribution to Recognition? Dilemmas of Justice in a "Post-Socialist" Age', New Left Review, Issue 212, July-August: 68-93.

Freeman, M. (2002) Human Rights: An Interdisciplinary Approach, Cambridge: Polity.

Giddens, A. (1998) The Third Way: The Renewal of Social Democracy, Cambridge: Polity.

Gough, I. (2002) 'Lists and Thresholds: Comparing our Theory of Human Need with Nussbaum's Capabilities Approach', paper to Conference on Promoting Women's Capabilities: Examining Nussbaum's Capabilities Approach, St. Edmund's College, Cambridge, 9-10 September.

Hopper, K. (2007) 'Rethinking Social Recovery in Schizophrenia: What a Capabilities Approach Might Offer', Social Science and Medicine, 65(5), 86879. 
Jackson, W. A. (2005) 'Capabilities, Culture and Social Structure', Review of Social Economy, 63(1): 101-24.

Joint Committee on Human Rights (2008) A Bill of Rights for the UK? Twentyninth Report of Session 2007-08, London: The Stationery Office.

Joseph, J. (1998) 'In Defence of Critical Realism', Capital and Class, Issue 65: 73-106.

Klees, S. J. (2002) 'World Bank Development Policy: A SAP in SWAPs Clothing', Current Issues in Comparative Education, 3(2): 110-21.

Klug, F. (2000) Values for a Godless Age: The History of the Human Rights Act and its Political and Legal Consequences, Harmondsworth: Penguin.

Layard, R. (2005) Happiness: Lessons from a New Science, London: Allen Lane.

Marshall, T. H. (1950) Citizenship and Social Class, and Other Essays, Cambridge: Cambridge University Press.

McLaughlin, E. (2007), 'From Negative to Positive Equality Duties: The Development and Constitutionalisation of Equality Provisions in the UK', Social Policy and Society, 6(1), 111-21.

Menon, N. (2002) 'Universalism Without Foundations?' Economy and Society, vol 31(1): 152-69.

Navarro, V. (2000) 'Development and Quality of Life: A Critique of Amartya Sen's Development as Freedom', International Journal of Health Services, vol 30(4): 661-74.

Novak, T. (1995) 'Rethinking Poverty', Critical Social Policy, 15, Issue 44/45: 58-74,

Nussbaum, M. (2000) Women and Human Development: The Capabilities Approach, Cambridge: Cambridge University Press.

Nussbaum, M. C. (2001) 'Symposium on Amartya Sen's Philosophy: Five Adaptive Preferences and Women's Options', Economics and Philosophy, 17(1): 67-88.

O'Connor, J. (2005) 'Policy Coordination, Social Indicators and the Social Policy Agenda in European Union', Journal of European Social Policy 15(4): 345-61.

Rawls, J. (1999) A Theory of Justice, Oxford: Clarendon Press, $2^{\text {nd }}$ revised edition.

Robeyns, I. (2005) 'The Capability Approach: A Theoretical Survey', Journal of Human Development, 6(1): 93-114. 
Rustin, M. (2007) 'What's Wrong With Happiness?', Soundings, Issue 36, Summer: 67-84.

Salais, R. and Villneueve, R. (2005) Europe and the Politics of Capabilities, Cambridge: Cambridge University Press.

Sandbrook, R. (2000) 'Globalization and the Limits of Neoliberal Development Doctrine', Third World Quarterly, 21(6): 1071-80.

Sayer, A. (2005) The Moral Significance of Class, Cambridge: Cambridge University Press.

Secretary of State for Justice and Lord Chancellor (2007) The Governance of Britain, London: The Stationery Office, CM 7170.

Sen, A. (1999) Development as Freedom, Oxford: Oxford University Press.

Sen, A (1985) 'A Sociological Approach to the Measurement of Poverty: A Reply to Professor Peter Townsend', Oxford Economic Papers, 37(4): 669-76.

Townsend, P. (1985) 'A Sociological Approach to the Measurement of Poverty - A Rejoinder to Professor Amartya Sen', Oxford Economic Papers 37(4): 659-68.

The Equalities Review (2007) Fairness and Freedom: The Final Report of the Equalities Review, London: TER.

http://archive.cabinetoffice.gov.uk/equalitiesreview/publications.html

Williams, F. (1989) Social Policy: A Critical Introduction, Cambridge: Polity.

Zimmerman, B. (2006) 'Pragmatism and the Capability Approach: Challenges in Social Theory and Empirical Research', European Journal of Social Theory 9(4): 467-84. 


\section{Figure 1}

\section{Nussbaum's List of Central Human Capabilities}

1 Life - a normal life expectancy

2 Bodily Health - good health including reproductive health

3 Bodily Integrity - free movement, protection from violence, including sexual assault

4 Senses, imagination and thought - a range of issues including creativity, artistic and political expression, and enjoyment of pleasure

5 Emotions - emotional development and attachment, to love and be loved

6 Practical reason - to develop a conception of good, and make life plans

7 Affiliation - to be able to live for and in relation with others, to develop empathy, pursue justice and friendship

8 Other Species - relations with the natural world and animals

9 Play - to laugh and play and relax

10 Control over one's environment - this includes political participation, material control over resources, and employment rights

(Nussbaum 1998: 83-5) 
Figure 2

The Equalities Review List of Central and Valuable Capabilities for Adults

1 To be alive

2 To live in physical security

3 To be healthy

4 To be knowledgeable, to understand and reason, and to have the skills to participate in society

5 to enjoy a comfortable standard of living, with independence and security

6 To engage in productive and valued activities

7 To enjoy individual, family and social life

8 To participate in decision-making, have a voice and influence

9 Of being and expressing yourself, and having self-respect

10 Of knowing you will be protected and treated fairly by the law

Source: Adapted from FR: 127-30 